\title{
Lightning-strike-induced acute lung injury: a case report
}

\author{
(1) Melahat Uzel Şener, M.D., ${ }^{1}$ (1) Ali Demir, M.D., ${ }^{2}$ (1) Alp Şener, M.D. ${ }^{3}$
}

\author{
${ }^{1}$ Department of Chest Disease, University of Health Sciences Ankara Atatürk Chest Diseases and Chest Surgery Training and Research \\ Hospital, Ankara-Turkey \\ ${ }^{2}$ Department of Anesthesiology and Reanimation, Medicana Health Group, İstanbul-Turkey \\ ${ }^{3}$ Department of Emergency Medicine, Ankara Atatürk Training and Research Hospital, Ankara-Turkey
}

\begin{abstract}
Lightning strike is an environmental electrical injury with high rates of morbidity and mortality. Lightning strike injuries are also considered to be high-voltage injuries. Respiratory injuries associated with lightning strikes include pulmonary edema, pulmonary contusion, acute respiratory distress syndrome, and pulmonary hemorrhage. In addition to direct damage, the affected patients are also exposed to secondary trauma; similarly, many other mechanisms associated with lightning injury have the same risk. It will therefore always be a rational approach to evaluate patients as multiple trauma patients. In this case report, a 19-year-old patient was admitted to the emergency department with amnesia, disorientation, shortness of breath, abdominal pain complaints and lung contusion, and myopathy signs as a result of a lightning strike in open terrain. The patient had a blood pressure of $80 / 50 \mathrm{mmHg}$, a heart rate of II0/min, and oxygen saturation of $85 \%$. Bilateral lung contusion and pleural effusion were detected on the computerized tomography of the thorax. In addition, global cardiac hypokinesia and the $20 \%-25 \%$ ejection fraction were detected on echocardiography. The central nervous system and abdominal scans were normal. The patient was admitted to the intensive care unit and treated with supportive oxygen, intravenous hydration, antibiotics, systemic steroids, and invasive cardiac monitoring. On the $10^{\text {th }}$ day of admission to the hospital, the patient was discharged with clinical and radiological improvement. On the $20^{\text {th }}$ day after discharge, tomography scans showed no thoracic pathologic findings.
\end{abstract}

Keywords: Environmental emergency; high-voltage injury; lightning strike; lung injury; myopathy.

\section{INTRODUCTION}

Electrical injuries constitute up to $2 \%-5 \%$ of admissions to the specialized burn centers. In these cases, the severity of the injury and mortality is associated with voltage. The highest mortality group is the lightning strike cases, with $17.6 \% .^{\left[{ }^{[}\right]}$

About 50 lightning events take place each second on the Earth's surface. An estimated 24,000 annual deaths associated with lightning strikes occur in the world. ${ }^{[2]}$ Lightning can affected people by direct strike, contact injury, side flash, the ground current by pressure or shock wave paths. Also, victims may get injured or die indirectly by reasons such as falling, hit by an object, smoke inhalation, and fire. ${ }^{[3]}$ Penetrating injuries related to a lightning strike caused by shrapnel from the explosion of a nearby structure have also been reported. ${ }^{[4]}$

In this case, bilateral lung contusion due to a direct effect of a lightning strike was detected, which is seen relatively rarely.

\section{CASE REPORT}

A 19-year-old male patient was admitted to the emergency department with complaints of severe abdominal pain and shortness of breath as a result of a very close lightning strike I day ago. The patient who fainted during the event and af-

Cite this article as: Uzel Şener M, Demir A, Şener A. Lightning-strike-induced acute lung injury: a case report. Ulus Travma Acil Cerrahi Derg 2019;25:198-201.

Address for correspondence: Melahat Uzel Şener, M.D.

Sanatoryum Hastanesi, 7. Göğüs Hastalıkları Kliniği, Keçiören, Ankara, Turkey.

Tel: +90 312 - 5677000 E-mail: melahatuzeldr@yahoo.com.tr

Ulus Travma Acil Cerrahi Derg 2019;25(2):198-20I DOI: 10.5505/tjtes.2018.4I86I Submitted: 07.05.20I8 Accepted: 22.10.20I8 Online: I4.03.20I9

Copyright 2019 Turkish Association of Trauma and Emergency Surgery 
ter that had no significant complaint was admitted because of the emergence of complaints and condition aggravation. The patient who had no known morbidities received intensive care with complaints of hypoxia and amnesia. Vital signs on admission were the following: blood pressure, $80 / 50 \mathrm{mmHg}$; heart rate, I 10 beats/min; respiratory rate, I8/min; and partial $\mathrm{O}_{2}$ saturation, $85 \%$. Retrograde amnesia and time orientation impairment were observed on the neurological examination. Breath sounds were diminished. There were no pathological findings on abdominal examination. There was no peripheral edema. The patient had slight burns up to $2-3 \mathrm{~cm}$ on the abdominal skin and the extensor side of the legs. Laboratory tests on admission showed the following findings: aspartate aminotransferase (AST), $249 \mathrm{U} / \mathrm{L}$; alanine aminotransferase (ALT), $206 \mathrm{U} / \mathrm{L}$; creatine kinase, I $163 \mathrm{U} / \mathrm{L}$; LDH, $614 \mathrm{U} / \mathrm{L}$; Na, $130 \mathrm{mmol} / \mathrm{L}$; K, $3.3 \mathrm{mmol} / \mathrm{L}$; white blood cell count, 22000/L; hemoglobin, I7.2g/dl; Plt, 394000/l; and normal urinalysis. Sinus tachycardia was present on electrocardiogram. On echocardiography, cardiac global hypokinesia and $20 \%-25 \%$ ejection fraction were detected. There was no obvious pathology found on brain and abdominal computed tomography. Computed tomography of the thorax revealed bilateral pleural effusion that was $1.2 \mathrm{~cm}$ on the right and $0.8 \mathrm{~cm}$ on the left, and there were patchy consolidations in the upper lobes, especially in the posterior region, and areas of ground glass opacities around it; no atelectasis was detected (Fig. I). The patient was admitted to the intensive care unit. Supportive oxygen of 2 liters per minute and intravenous $0.9 \% \mathrm{NaCl}$ hydration were started. The possibility of infection could not be ruled out

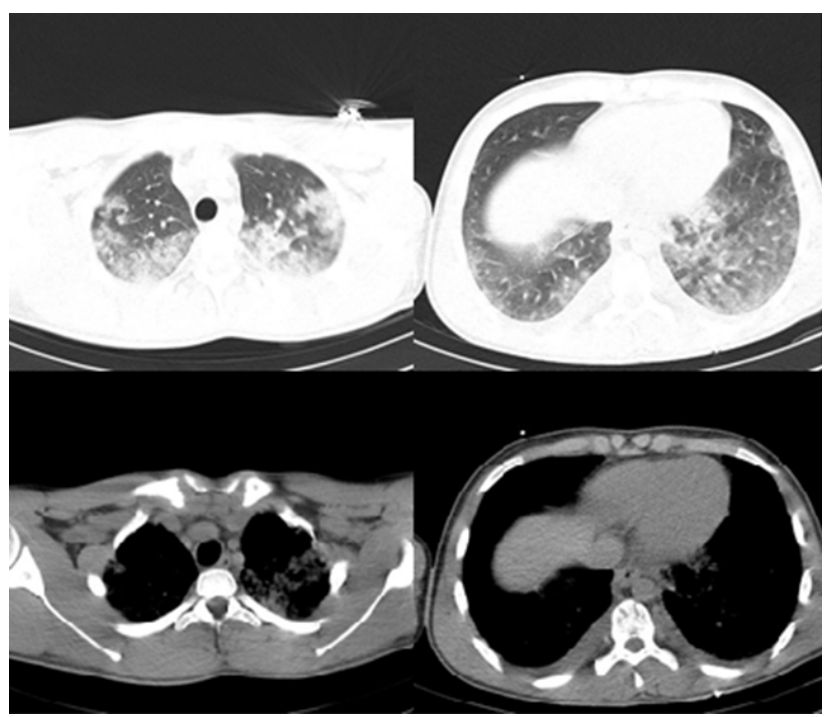

Figure 1. Thorax tomography during hospital admission.

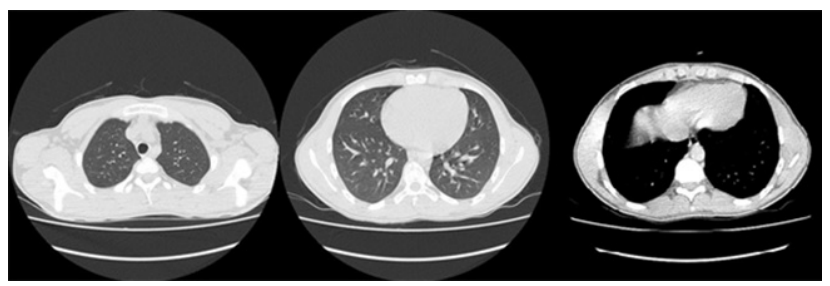

Figure 2. Thorax tomography after treatment. due to leukocytosis and the appearance of the ground glass opacities on tomography and unreliable history on the initial evaluation, therefore antibiotics (intravenous clarithromycin; $500 \mathrm{mg}$ twice a day) were started. Systemic steroids (methylprednisolone; $40 \mathrm{mg}$ once a day) were added to prevent the alveolar damage due to lung contusion. During the follow-up, the creatine kinase and liver function tests returned to normal (AST, $19 \mathrm{U} / \mathrm{L}$; ALT, $25 \mathrm{U} / \mathrm{L}$; creatine kinase, $108 \mathrm{U} / \mathrm{L}$ ). On the echocardiography follow-up, systolic functions were improved, and ejection fraction rose to $60 \% . \mathrm{O}_{2}$ saturation increased to $98 \%$. After the improvement of symptoms, the patient was discharged. There were no pathological findings on chest computed tomography on the $20^{\text {th }}$ day after treatment (Fig. 2). The patient was not admitted to the hospital for his follow-up examination, but he was known to be alive without neurological sequelae and complaints at the $6^{\text {th }}$ month follow-up.

\section{DISCUSSION}

Lightning strikes often tend to happen in men who are in the 4th decade of life, and in the months of July and August. Injury mechanisms include thermal effects, electrical effects, the effects of magnetic fields, explosive effects, and blunt trauma due to falls. Direct strikes are likely to cause the most serious clinical presentation..$^{[5]}$ In our case, a direct impact mechanism was involved, and serious injuries on multiple systems were reported.

Cardiovascular system changes due to lightning strike vary from benign changes to sudden cardiac death. The ST elevation, QT prolongation, cardiomyopathy, atrial fibrillation, and an increase in cardiac markers may occur as initial signs. A sudden death in a lightning strike manifests as a cardiac and respiratory arrest, which often would happen at the same time. The initial arrest rhythm is typically asystole, but it can present as ventricular fibrillation. ${ }^{[2,6]}$ In the literature, serious clinical presentations associated with lightning are available, including acute myocardial infarction and cardiac arrest. ${ }^{[6]}$ Deterioration of the ventricular ejection fraction is generally seen to be transient. [7] In our case, global hypokinesia have been identified, and a transient decrease in ejection fraction has been detected; however, there was no need for any interventions except invasive monitoring and follow-up. In the case of a lightning strike, the burns and cardiovascular system disorders require immediate attention and quick interventions. Procedures that are first and urgently to be done are the electrocardiogram and echocardiography. ${ }^{[2,6]}$ Also, in these cases, vigorous and prolonged resuscitation is recommended. ${ }^{[6]}$

Neurological symptoms include loss of consciousness, seizures, headache, paresthesia, weakness, and as in this case, temporary early-onset findings such as memory loss and disorientation. ${ }^{[2,8]}$

The Lichtenberg figures (fern-leaf pattern) are typical skin findings for lightning injury. ${ }^{[9]}$ However, burns are the main 
problem. The pathologies can be seen including full-thickness burns that can lead to death. ${ }^{[10]}$

Blunt trauma to other organs such as the spleen, liver, lungs, and bowels is possible due to shock waves or falling or being hit with an object. ${ }^{[5]}$ However, pulmonary injury cases are frequent. High-voltage-dependent isolated lung injuries have been reported in only a small number of case reports. These results confirm the likely higher mortality of the transthoracic current transition. ${ }^{[1]}$ Parallel with these findings, Ströhle et al. ${ }^{[I]}$ reported 64 patients who were exposed to a lightning strike, indicating that $6.3 \%$ of these patients died, and $10.9 \%$ had serious injuries. No lung injury was reported in any of the cases in this study. Van Waes et al. ${ }^{[4]}$ have presented a case with a penetrating lung injury due to shrapnel from the explosion of a nearby structure as a result of a lightning strike; in this report, the need to accept the lightning strikes that cause blunt trauma by different mechanisms as high-energy trauma was emphasized. In addition, in a study by Wankhede et al., ${ }^{[12]}$ a fatal case of burn injury beneath a piece of lac jewelry and associated contusion of both the lung anterior border and left lung lingula were presented as autopsy findings.

Cooray et al. ${ }^{[5]}$ stated that if the lightning current transition passes over the respiratory centers such as the brain stem, pons, or medulla, it may cause the central hypoventilation, and as a result, it can lead to complications including respiratory arrest. In such cases, according to the resuscitation guidelines, routine algorithms are recommended. ${ }^{[6]}$

In the lightning strike case described by Dhawan et al., ${ }^{[13]}$ as it was in our case, the middle and upper lobes of the lung were involved radiologically, but the lower lobes were protected. This involvement is considered as bilateral hydrostatic pulmonary edema due to cardiac injury, and it was stated that it was less frequent than the direct damage of the lung due to the effect of the concussion. It has been reported that this involvement is considered to be associated with bilateral hydrostatic pulmonary edema due to cardiac damage, and this mechanism is less common than direct injury of the lung due to the blast effect. We interpret our own case as a lung contusion directly connected to the damage. However, a global cardiac damage is similar in both cases. In our case, it is also evident that the cardiac involvement would have a secondary effect to the lungs. Blumenthal et al. ${ }^{[14]}$ reported a case of pneumomediastinum due to lightning strike. In this study, it is stated that the damage is associated with barotrauma due to the lightning's blast wave. In addition, Halldorsson et al. ${ }^{[5]}$ estimated that the pneumomediastinum was related to a sudden large fluctuation in temperature close to the victim's body. These two mechanisms may also have an effect on the damage in our case.

In an animal study, it was concluded that lung microcirculation disorders play an important role in the damage due to electrical burns associated with the high-voltage. ${ }^{[16]}$ Direct damage to the cell membrane lipid barrier causes the formation of membrane pores. ${ }^{[6]}$ Rather than this mechanism, the absence of serious burns in this case suggests that the damage might be due to a direct effect on the lungs by lightning. In another study, it is stated that high-voltage-dependent burns may cause pulmonary infarction by direct effect of electrical current or vascular embolism; additionally, it is stated that there is no way to prevent necrosis and microvascular thrombosis developed due to electrical injury. ${ }^{[17]}$

\section{Conclusion}

Lightning is a rare cause of the emergency department visits. Although pulmonary involvement is rare, it should always be kept in mind, as well as the lightning-induced primary lung damage. Various mechanisms of trauma to the thorax or secondary effects due to cardiac damage should be taken into consideration as well. Lightning strike injuries should be handled as high-energy trauma. However, most of the time conservative approaches and support are sufficient. Lung contusion due to high-voltage electrical injuries should be followed with a strict vital signs monitoring. In these patients, fluid resuscitation is extremely important; however, complications due to excessive fluid overload in the damaged lung should be also carefully considered. If necessary, resuscitation should be performed in accordance with the recommendations of the American Heart Association and European Resuscitation Council guidelines. Resuscitation of lightning strike cases are considered to be successful than usual; therefore, physicians should apply vigorous and prolonged resuscitation.

\section{Financial/Material Support: None}

\section{Disclosures: None}

Author Contributions: All authors made substantial contributions to the acquisition of data and/or interpretation of data. All authors participated in drafting the article or revising it critically for important intellectual content. All authors gave their final approval of the version to be submitted and any revised version.

\section{Conflict of interest: None declared.}

\section{REFERENCES}

1. Schleich AR, Schweiger H, Becsey A, Cruse CW. Survival after severe intrathoracic electrical injury. Burns 2010;36:e61-4. [CrossRef]

2. Davis C, Engeln A, Johnson EL, McIntosh SE, Zafren K, Islas AA, et al; Wilderness Medical Society. Wilderness Medical Society practice guidelines for the prevention and treatment of lightning injuries: 2014 update. Wilderness Environ Med 2014;25:S86-95. [CrossRef]

3. Elsom DM. Deaths and injuries caused by lightning in the United Kingdom: Analyses of two database. Atmospheric Research 2001;56:325-34.

4. van Waes OJ, van de Woestijne PC, Halm JA. “Thunderstruck”: penetrating thoracic injury from lightning strike. Ann Emerg Med 2014;63:457-9.

5. Cooray V, Cooray C, Andrews CJ. Lightning caused injuries in humans. Journal of Electrostatics 2007;65:386-94. [CrossRef] 
6. Ritenour AE, Morton MJ, McManus JG, Barillo DJ, Cancio LC. Lightning injury: a review. Burns 2008;34:585-94. [CrossRef]

7. Saglam H, Yavuz Y, Yurumez Y, Ozkececi G, Kilit C. A case of acute myocardial infarction due to indirect lightning strike. J Electrocardiol 2007;40:527-30. [CrossRef]

8. Rahmani SH, Faridaalaee G, Jahangard S. Acute transient hemiparesis induced by lightning strike. Am J Emerg Med 2015;33:984.e1-3. [CrossRef]

9. Domart $\mathrm{Y}$, Garet $\mathrm{E}$. Images in clinical medicine. Lichtenberg figures due to a lightning strike. N Engl J Med 2000;343:1536. [CrossRef]

10. Forster SA, Silva IM, Ramos ML, Gragnani A, Ferreira LM. Lightning burn-review and case report. Burns 2013;39:e8-12. [CrossRef]

11. Ströhle M, Wallner B, Lanthaler M, Rauch S, Brugger H, Paal P. Lightning accidents in the Austrian alps - a 10-year retrospective nationwide analysis. Scand J Trauma Resusc Emerg Med 2018;26:74. [CrossRef]
12. Wankhede AG, Agrawal VR, Sariya DR. An injury subjacent to lac ornament in a case of lightning. Forensic Sci Int 2010;195:e9-12. [CrossRef]

13. Dhawan S, Sultan-Ali IA. Lightning-induced ECG changes and hydrostatic pulmonary edema. Clin Cardiol 2009;32:E71. [CrossRef]

14. Blumenthal R, Saayman G. Case Report: Lightning-Induced Pneumomediastinum. Am J Forensic Med Pathol 2017;38:94-96. [CrossRef]

15. Halldorsson A, Couch MH. Pneumomediastinum caused by a lightning strike. J Trauma 2004;57:196-7. [CrossRef]

16. Zhou HM, Xu SJ, Wang L, Shao HB, Xie B, Feng JK, et al. Influences of high-voltage electrical burns on the pulmonary microcirculation in rabbits. Clin Hemorheol Microcirc 2016;62:193-203. [CrossRef]

17. Li YY, Min L, Huang J, Wang JL, Jiao LR. Successful treatment of a case of severe electrical burns with heart and lung injuries. J Burn Care Res 2007;28:762-6. [CrossRef]

\section{OLGU SUNUMU - ÖZET}

\section{Yıldırım çarpması kaynaklı akut akciğer hasarı: Olgu sunumu \\ Dr. Melahat Uzel Şener, ${ }^{1}$ Dr. Ali Demir, ${ }^{2}$ Dr. Alp Şener ${ }^{3}$}

${ }^{1}$ Sağlık Bilimleri Üniversitesi, Ankara Atatürk Göğüs Hastalıkları ve Göğüs Cerrahisi Eğitim ve Araştırma Hastanesi, Göğüs Hastalıkları Kliniği, Ankara ${ }^{2}$ Medicana Sağlık Grubu, Anesteziyoloji ve Reanimasyon Kliniği, İstanbul

${ }^{3}$ Ankara Atatürk Eğitim ve Araştırma Hastanesi, Acil Tıp Kliniği, Ankara

Yıldırım çarpması, yüksek oranda morbidite ve mortaliteye sahip bir çevresel elektrik acilidir. Yıldıım çarpmasına bağlı yaralanmalar yüksek voltaj yaralanmaları olarak isimlendirilir. Yıldıım çarpmasıyla ilişkili solunumsal yaralanmalar arasında pulmoner ödem, pulmoner kontüzyon, akut solunum sıkıntısı sendromu ve pulmoner hemoraji sayılabilir. Yüksek voltajla ilişkili birçok farklı mekanizmada olduğu gibi direkt hasarın yanında bu hastalar sekonder travmalara da maruz kalmaktadır. Dolayısıyla hastaların multitravma hastası olarak değerlendirilmesi her zaman akılcı yaklaşım olacaktır. Bu yazıda, 19 yaşında bir hasta, açık arazide gerçekleşen yıldırım çarpmasına direkt maruziyet sonucu amnezi, oryantasyon bozukluğu, nefes darlığı ve karın ağrısı şikayetleri, akciğer kontüzyonu ve miyopati bulguları ile acil servise başvurdu. Vital bulgularında; kan basıncı $80 / 50 \mathrm{mmHg}$, kalp hızı I I0/dakika, oksijen satürasyonu \%85 olarak ölçüldü. Hastanın akciğer tomografisinde iki taraflı akciğer kontüzyonu ve plevral effüzyon saptandı. Ayrıca hastanın yapılan ekokardiyografisinde global kardiyak hipokinezi ve \%20-25 ejeksiyon fraksiyonu saptandı. Hastanın santral sinir sistemi ve abdominal görüntülemeleri doğaldı. Hasta, yoğun bakım ünitesine yatırıldı ve destek oksijen, intravenöz hidrasyon, antibiyotik, sistemik steroid ve invaziv kardiyak monitörizasyon ile tedavi ve takip edildi. Hastaneye yatııılmasının onuncu gününde klinik ve radyolojik iyileşme sağlanan hasta taburcu edildi. Taburculuk sonrası 20. günde çekilen tomografide toraksta patolojik bulgu kalmadığı görüldü.

Anahtar sözcükler: Akciğer yaralanması; çevresel aciller; miyopati; yıldırım çarpması; yüksek voltaj yaralanması.

Ulus Travma Acil Cerrahi Derg 2019;25(2):198-201 doi: 10.5505/tjtes.2018.41861 